\title{
A Study on Impulse Buying Behaviour of Consumers towards Apparels with reference to In-store Environment
}

\author{
Pooja $^{1}$, Sanjiv Mittal ${ }^{2}$ and Kamakshi ${ }^{3}$ \\ ${ }^{1}$ Associate Professor, Rukmini Devi Institute of Advanced Studies, GGSIPU, New Delhi, India. \\ ${ }^{2}$ Professor, University School of Management Studies, GGSIPU, New Delhi, India. \\ ${ }^{3}$ Research Analyst, Grail Research, Noida, Uttar Pradesh, India.
}

CITATION: Pooja; Mittal, Sanjiv and Kamakshi (2019), "A Study on Impulse Buying Behaviour of Consumers towards Apparels with reference to In-store Environment", MERC Global's International Journal of Management, Vol. 7, Issue 1, pp. 01-08.

ARTICLE HISTORY: Submitted: July 14, 2018, Revision received: August 15, 2018, Accepted: August 25, 2018

ARTICLE TYPE: Research paper

\begin{abstract}
The objective of this paper was to study the relationship between in-store shopping environment and impulsive buying behaviour of consumers and to analyse the most important instore environment factor influencing impulsive buying behaviour towards apparels. The study was descriptive research design and convenience sampling is used as sample design. A questionnaire was distributed among 300 respondents both male and female from Delhi NCR. Factor analysis was used to calculate the significance of the factors. Regression Analysis has shown the relationship between in-store shopping environment and impulsive buying behaviour of consumers towards apparels reflecting the most significant and not significant factor.
\end{abstract}

KEYWORDS: Apparels, Impulse buying behaviour, Hedonic effects, In-store environment.

\section{REFERENCES}

1. Babin, B. J.; Lee, Y. K.; Kim, E. J. and Griffin, M. (2005), "Modelling Consumer Satisfaction and Wordof-mouth: Restaurant Patronage in Korea," Journal of Services Marketing, Vol. 19, Issue 3, pp. 133-139.

2. Badgaiyan, A. J. and Verma, A. (2014), "Intrinsic factors affecting impulsive buying behaviour Evidence from India", Journal of Retailing and Consumer Services, Vol. 21, pp. 537-549.

3. Ballantine, Paul W.; Jack, Richard and Parsons, Andrew G. (2010), "Atmospheric cues and their effect on the hedonic retail experience", International Journal of Retail \& Distribution Management, Vol. 38, Issue 8, pp. 641-653.

4. Beverland, Michael; Lim, Elison Ai Ching; Morrison Michael and Terziovski, Milé (2006), "In-store music and consumer-brand relationships: Relational transformation following experiences of (mis)fit", Journal of Business Research, Vol 59, Issue 9, pp. 982-989.

5. Brar, Vinaydeep and Kumar, Atul (2017), "Customer Satisfaction towards the Services rendered by Superstore Retailers", International Journal of Science, Technology and Management, Vol. 6, Issue 7: July, pp. 111-117.

6. Brar, Vinaydeep; Kumar, Atul; Patil, Nitin A. and Gade, Santosh (2017), "An Analysis of Key Growth Drivers and Challenges in Organised Sector of Indian Retail Industry", Siddhant Management Review, Vol. 2, Issue 1, pp. 29-40.

7. Chebat, J. and Michon, R. (2003), "Impact of ambient odours on mall shoppers' emotions, cognition, and spending a test of competitive causal theories", Journal of Business Research, Vol. 56, pp. 529-539.

8. Crawford, G. and Melewar, T. C. (2003), "The importance of impulse purchasing behaviour in the international airport environment", Journal of Consumer Behaviour, Vol. 3, Issue 1, pp. 85-98.

9. Dingfelder, S. (2005), "Music motivates impulse buyers, not thoughtful shoppers", American Psychological Association, Vol. 36, Issue 10, pp. 17.

10. Dubé, L. and Morin, S. (2001), "Background music pleasure and store evaluation: intensity effects and psychological mechanisms”, Journal of Business Research, Vol. 54, Issue 2, pp. 107-113. 
11. Garlin, F. V. and Owen, K., (2006), "Setting the tone with the tune: A meta-analytic review of the effects of background music in retail settings", Journal of Business Research, Vol. 59, pp. 755-764.

12. Goyal, B. B. and Mittal, A. (2007), "Gender Influence on Shopping Enjoyment: An Empirical Study", Indian Management Studies Journal, Vol. 11, Issue 2, pp. 103-116.

13. Graa, A.; Dani-Elkebir, M. and Bensaid, M. (2014), "The impact of Environmental Factors on Impulse Buying Behaviour Using the Mehrabian and Russell's Framework", Leonardo Journal of Sciences, Vol. 13 (24), pp. 101-114.

14. Kumar, Atul (2011), "Demographic \& Geographic Inclination towards Store Design: A Study of Shopping Mall Customers in Maharashtra-State, India”, Asian Journal of Management, Vol. 2, Issue 3: July-Sept, pp. 87-93.

15. Kumar, Atul (2012), "Store Image - A Critical Success Factor in Dynamic Retailing Environment: An Investigation", Asian Journal of Management, Vol. 3, Issue 1: January-March, pp. 01-05.

16. Kumar, Atul (2012), "The Changing Buying Behaviour of Customers in Organised Retail Sector of Pune City”, International Journal of Research in Social Sciences, Vol. 2, Issue 1: February, pp. 242-263.

17. Kumar, Atul (2016), Retailing Strategy of Products \& Customer Services in Organised Retail Sector, PhD Thesis Submitted to Shri Jagdishprasad Jhabarmal Tibrewala University, Vidyanagari, Rajasthan.

18. Kumar, Atul and Brar, Vinaydeep (2012), "Measurement of the Demographic Inclination towards Store Image", Vishwakarma Business Review, Vol. 2, Issue 2, July, pp. 88-93.

19. Kumar, Atul and Brar, Vinaydeep (2016), Retailing Strategy: Products \& Customer Services Perspective, LAP LAMBERT Academic Publishing, Germany, available at: https://www.lappublishing.com/catalog/details//store/gb/book/978-3-330-01953-9/retailing-strategy.

20. Lam, Shun Yin (2001), "The Effects of Store Environment on Shopping Behavior: a Critical Review", in NA - Advances in Consumer Research, Volume 28, eds. Mary C. Gilly and Joan Meyers-Levy, Valdosta, GA: Association for Consumer Research, pp. 190-197.

21. Lucas, M. and Koff, E (2014), "The role and of self-perceived attractiveness in impulse buying in women", Personality and Individual Differences, Vol. 56, pp. 111-115.

22. Mattila, A. S. and Wirtz, J. (2001), "Congruency of scent and music as a driver of in-store evaluations and behaviour", Journal of Retailing, Vol. 2, pp. 273-289.

23. Mattila, Anna S. and Wirtz, Jochen (2008), "The Role of Store Environmental Stimulation and Social Factors on Impulse Purchasing”, Journal of Services Marketing, Vol. 22, Issue 7, pp. 562-567.

24. Maya, Pun Wai Man (2014), Store Environment Effects On Impulse Buying Behaviour Of International Streetwear Flagship Stores, Institute of Textile \& Clothing The Hong Kong Polytechnic University.

25. Mohan, G.; Sivakumaran, B. and Sharma, P. (2013), "Impact of store environment on impulse buying behaviour", European Journal of Marketing, Vol. 47, Issue 10, pp. 1711-1732.

26. Morrison, M.; Gan, S.; Dubelaar, C. and Oppewal, H. (2011), "In-store music and aroma influences on shopper behaviour and satisfaction”, Journal of Business Research, Vol. 64, Issue 6, pp. 558-564.

27. Muruganantham, G. and Bhakar, R. S. (2013), “A Review of Impulse Buying Behaviour”, International Journal of Marketing Studies, Vol. 5, Issue 3, pp. 149-160.

28. Nanda, Ankita (2015), “Analysing Multiple Dimensions of Impulse Buying”, MERC Global's International Journal of Management, Vol. 3, Issue 3, pp. 105-115.

29. Peck, J. and Childers, T. L. (2006), "If I touch it, I have to have it: individual and environmental influences on impulse purchasing”, Journal of Business Research, Vol. 59, Issue 6, pp. 765-769.

30. Shareef, P. and Krishnan, C. (2018), "Service Quality of the Retail Sector in India”, MERC Global's International Journal of Management, Vol. 6, Issue 2, pp. 32-36.

31. Sharma, Arun and Stafford, Thomas F. (2000), "The Effect of Retail Atmospherics on Customers' Perceptions of Salespeople and Customer Persuasion: An Empirical Investigation”, Journal of Business Research, Vol. 49, Issue 2, pp. 183-191.

32. Sharma, P. and Sivakumaran, B. (2004), "Impulse Buying and Variety Seeking: Two Faces of the Same Coin? Or Maybe Not!”, Advances in Consumer Research, Vol. 31, pp. 260-261.

33. Simonson, I. (1999), "The effect of product assortment on buyer preference", Journal of Retailing, Vol. 75, Issue 3, pp. 347-370.

34. Summers, T. A. and Hebert, P. R. (2001), "Shedding some light on store atmospherics influence of illumination on consumer behaviour", Journal of Business Research, Vol. 54, Issue 2, pp. 145-115.

35. Tang, Christopher S. (2006), "Perspectives in supply chain risk management", International Journal of Production Economics, Vol. 103, Issue 2, pp. 451-488.

36. Terrazas, M. (2006), "In-store displays that work", The Baker, Vol. 10, Issue 3.

37. Tinne, W. S. (2010), "Impulse Purchasing: A Literature Overview", ASA University Review, Vol. 4, Issue 2 , pp. 65-73.

38. Turley, L. W. and Chebat, Jean-Charles (2002), "Linking Retail Strategy, Atmospheric Design and Shopping Behaviour", Journal of Marketing Management, Vol. 18, Issue 1-2, pp. 125-144.

39. Yu, C. and Bastin, M. (2010), "Hedonic shopping value and impulse buying behaviour in transitional economies: A symbiosis in the Mainland China marketplace”, Journal of Brand Management, Vol. 18, Issue 2, pp. 105-114.

40. Zhou, L. and Wong, A. (2003), "Consumer impulse buying and in-store stimuli in Chinese supermarkets”, Journal of International Consumer Marketing, Vol. 16, Issue 2, pp. 37-53. 